\title{
The Effect of Auditing Quality and Independent Board of Commissioners on Financial Performance of Property and Real Estate Companies In Indonesia
}

\author{
Aminar Sutra Dewi ${ }^{1}$, Febsri Susanti ${ }^{2}$, Maria Magdalena ${ }^{3}$, Dewi Zulvia ${ }^{4}$, Jhon \\ Fernos $^{5}$ \\ 1Sekolah Tinggi Ilmu Ekonomi KBP, Padang, Indonesia \\ $\triangle$ (e-mail) aminarsd@gmail.com \\ 2Sekolah Tinggi Ilmu Ekonomi KBP, Padang, Indonesia \\ $\triangle$ (e-mail) febsri26@gmail.com \\ ${ }^{3}$ Sekolah Tinggi Ilmu Ekonomi KBP, Padang, Indonesia \\ $\triangle$ (e-mail) memey1968@gmail.com \\ 4Sekolah Tinggi Ilmu Ekonomi KBP, Padang, Indonesia \\ $\triangle$ (e-mail) febsri26@gmail.com \\ ${ }^{5}$ Akademi Keuangan dan Perbankan "Pembangunan", Padang, Indonesia \\ $\bowtie$ (e-mail) jfernos67@gmail.com
}

\begin{abstract}
The decline in stock prices of property and real estate firms resulted from the government's policy of high loan interest has not affected the property sector and real estate. This study aims to examine the effect of good corporate governance implementation that is the quality of auditor (AQ) to financial performance and proportion of independent board of commissioner (ICs) to company financial performance. This research uses the purposive sampling method that is sampling technique which refers to certain criteria. Based on predetermined criteria, 23 companies will be selected as research samples in 2012 until 2016. The method of analysis used is the quantitative method, with classical assumption test and panel data regression analysis. From the three tests obtained the best model is Fixed Effect Model (FEM). The results of this study indicate that audit quality has the positive and insignificant effect on financial performance as reflected in return on equity. While the proportion of independent board of commissioners has a negative and significant impact on financial performance as reflected in return on equity.
\end{abstract}

Keywords: audit quality, the proportion of independent board of commissioners, and financial performance

\section{Introduction}

Company's performance is an important factor for investors to consider before investing. Therefore, the performance of the company/institution should be continuously improved. Financial performance is a reflection of how well the company's management refers to the published financial statements for a given period usually measured by aspects of capital adequacy, liquidity, and profitability (Aziz \& Hartono, 2017). So, the company's financial performance analyzes the success rate to see how far the company has implemented the rules appropriately. A company's performance assessment can be used as a tool to conduct an analysis that depends on the thinking of the owner, the creditor, and the manager.

The policies and decisions of investors in investing are more influenced by the ratio of profitability owned by a company than other ratios, as investors assume that profitability can give an idea of the level of profit that will be obtained from the investment. Goal achieved to attract stakeholders to be able to help support operational performance is an improvement in the company. One of the assessments of financial performance performed by company and shareholder is the return on equity. To know the value of return on equity, then the company must analyze again the financial performance of the company at a certain period. The more return the company produces then the owner of the company also the better (Djazilah \& Kurnia, 2016). 
According to Hasanah et al. (2017) the more property and real estate companies listed on the Indonesia Stock Exchange, the more stringent the competition between companies. Thus, it encourages companies in improving financial performance. The development of Property and Real Estate industry grow faster and increase every year. It is because the land has a fixed availability while the population of Indonesia continues to increase every year. In addition, during the administration of President Jokowi, Indonesia continues to develop infrastructure to support the economy. In improving quality of life, low-income people getting a house become a priority for the government. Some developers suspect that 2017 is not an appropriate year to raise the property sector. In the Economic sector, the decrease of loan interest, relaxation of the loan to value, discounted sales tax, licensing deregulation, giving tax amnesty are the stimulus provided by the government to encourage growth. However, it does not go smoothly, even in 2017 property conditions are still running slowly.

The problem of this research is the decline of the stock price of property and real estate companies caused by government policy that the credit interest is still high and has no influences on the property and real estate sector because the funds used for investments are not always significant and the returns from property investment are not attractive enough. Declining stock prices result in lower sales because the investors do not want to invest in the property and real estate sectors, a decrease in sales will affect the company's financial performance that if sales decline, the company's financial performance becomes less good.

Good Corporate Governance influences the company's financial performance. Good Corporate Governance is a concept based on agency theory, which is expected to serve as a tool to convince investors that they will get benefit from the funds that have been invested. The implementation of corporate governance is useful to improve the company's performance in the decision-making process more precisely. The company's operations efficiently can be improved by providing more services to stakeholders (Kusdiyanto \& Kusmaningrum, 2015). This study investigates the effect of Good Corporate Governance (GCG) implementation that is quality of auditor (AQ) and proportion of independent commissioner board (ICs) to company financial performance.

According to Djazilah and Kurnia (2016), several studies have found that big auditing firms with high reputations can provide the better quality of auditing, so it improves corporate transparency and corporate governance. The effectiveness of supervisory functions performed by the audit committee can improve financial performance. Audit quality is a possibility that an auditor can find and report errors in the client's accounting system. The auditor may find misstatements through the technical ability of the auditor while the act of reporting misstatements depends on the independence of the auditor. Audit quality is important because better audit quality will produce accurate and reliable financial reports as a basis for decision making (Hardiningsih, 2010). The better financial report, the better financial performance is.

Some previous studies have conducted empirical studies. Hardiningsih (2010) studied the influence of independence, corporate governance, and audit quality on the integrity of financial statements. The result indicated that audit quality variables had no significant effect on the integrity of financial statements. This result also tended to show that the better the quality of audit meant the better the auditor's expertise (specialization) is, the better the level of integrity of the financial statements is, and the better the financial statements are. Supported by Susanti (2011), the research was about the influence of corporate governance quality, audit quality, and earning management on company performance. The result showed that audit quality negatively affected company performance. It meant that audit quality would degrade the company's performance. Meanwhile, Setiawan (2015) studied the influence of independence, audit quality and corporate mechanisms on the integrity of corporate financial statements. The result was that the quality of audit affected the integrity of financial statements. Based on the description above, the hypotheses can be formulated as follows:

$\mathrm{H}_{1}$ Audit quality has a significant effect on financial performance 
The proportion of independent board of commissioners are members of the board of commissioners who are not affiliated with the directors, other members of the board of commissioners, the controlling shareholder, and are free from other business relationships that may affect their ability to act independently. This variable is measured by the percentage of total independent commissioners to the total number of members of the board of commissioners (Djazilah \& Kurnia, 2016). The monitoring function should be carried out by the independent commissioner in order to create a Good Corporate Governance company that has the best position (Eva \& Artinah, 2016). Supervision of independent board of commissioners aims to improve the performance of managers so it increases the performance of the company. The greater the proportion of independent commissioners is, the greater the power of the board of commissioners in pressuring the management for increased corporate performance.

Previous studies on the influence of corporate governance on financial performance have been widely implemented, such as Djazilah \& Kurnia (2016) who studied the effect of GCG mechanism and CSR disclosure on financial performance. The result showed that the proportion of independent board of commissioners had a significant influence on financial performance reflected on return on equity. Supported by the study of Prime, Putra \& Murni (2016) claimed that the board of independent commissioners had a positive influence on the financial performance of the company. Meanwhile, the research of Kusdiyanto \& Kusmaningrum (2015) was about the effect of good corporate governance and leverage to financial performance (study at manufacturing company listed in BEI 2013-2014). It revealed that independent commissioner had a significant negative effect on financial performance. Based on the description above, the hypotheses can be formulated as follows:

$\mathrm{H}_{2}$ Proportion of Independent Board of Commissioners has a significant effect on financial performance

\section{Methods}

This research was conducted by using a quantitative method in which the research data were based on numerical and statistical analyses (Sugiyono, 2015, 13). In other words, quantitative research is research expressed by numbers and can be calculated by using a certain formula.

The object of the research is everything that becomes the center of attention of someone in doing a research (Sugiyono, 2015). So, the objects of this study were the Property and Real Estate companies listed on the Indonesia Stock Exchange (BEI). This research was done at Jl. Jend. Sudirman Kav 52-53 Jakarta Selatan 12190, Indonesia.

A population is a region in general or a generalization of a subject/an object that has a certain quantity set by researchers to be studied and then drawn conclusions (Sugiyono, 2015, 92). So, the population is all the characteristics or properties possessed by the subject or the object studied. The population of this research was property and real estate companies listed on the BEI during 2012 to 2016, with a total population of 56 companies that have acknowledged by the public. The sample is a part of the number and characteristics possessed by the population to be studied. The sample in this research was obtained by using purposive sampling technique that is sampling technique which refers to certain criteria. Based on the criteria above, there were 23 companies chosen as the samples of this research.

The data were analyzed using a series of techniques as follows. First, panel data model analysis. There are three methods of panel data regression that is common effect model (CEM) method, fixed effect model (FEM), random effect model (REM).

1. Common Effect Model (CEM) method

This method describes cross-section data with time series and uses OLS method to estimate the panel data model. This model is the simplest model of the other two models. This model cannot distinguish the variance between the cross and not randomly vary. 
2. Fixed Effect Model (FEM) method

It is a model with different intercept for each subject (cross-section), but each subject does not change over time. This model assumes that the intercept is different from every other subject used dummy variables. This model is often called the Least Square Dummy Variable (LSDV) model.

3. Random Effect Model (REM) method

This method is caused by variations in the value and direction of the relationship between subjects assumed random specified in the residual form. This model estimates panel data that residual variables are suspected to have a relationship between subjects. This model is used to overcome the weakness of Fixed Effect model using dummy variable. Methods of panel data analysis with random effect method must meet the requirement that the number of the cross-section is greater than the number of research variables.

Table 1 The variables and operational definitions

\begin{tabular}{|c|c|c|c|}
\hline Variable & Definition & Measurement & Source \\
\hline $\begin{array}{l}\text { Financial } \\
\text { Performance } \\
(\mathrm{ROE})\end{array}$ & $\begin{array}{l}\text { Return on Equity is an ability } \\
\text { of the company to generate } \\
\text { profit with its own capital }\end{array}$ & $R O E=\frac{E A T}{i t^{\prime} \text { s own capital }} \times 100 \%$ & $\begin{array}{l}\text { (Sutrisno, } \\
2012)\end{array}$ \\
\hline Audit Quality & $\begin{array}{l}\text { Audit quality is known as a } \\
\text { combined probability to } \\
\text { detect and report material } \\
\text { errors in financial statements. }\end{array}$ & $\begin{array}{l}\text { All of the internal and external } \\
\text { auditors of the company. }\end{array}$ & $\begin{array}{l}\text { (Christiani } \\
\& \\
\text { Nugrahanti } \\
\text { 2014) }\end{array}$ \\
\hline $\begin{array}{l}\text { The proportion } \\
\text { of independent } \\
\text { board of } \\
\text { commissioner }\end{array}$ & $\begin{array}{l}\text { An independent board of } \\
\text { commissioners is a party that } \\
\text { is not allowed to have any } \\
\text { relationship to the } \\
\text { management of the } \\
\text { company. }\end{array}$ & $\begin{array}{l}\text { PDKI } \\
=\frac{\text { Independent commissioners }}{\text { total commisioners }} \times 100 \%\end{array}$ & $\begin{array}{c}\text { (Aziz \& } \\
\text { Hartono, } \\
\text { 2017) }\end{array}$ \\
\hline
\end{tabular}

Second, panel data regression analysis. The regression equations used in panel data analysis can be seen as follow:

where:

$$
\operatorname{ROE}_{i t}=\alpha+\beta_{1} A_{Q_{i t}}+\beta_{2} I_{C S i t}+e
$$

$\mathrm{ROE}=$ Return on Equity in $\mathrm{t}$ time

$\mathrm{AQ}_{\text {it }}=$ Audit quality in $\mathrm{t}$ time

ICsit $=$ proportion of independent board of commissaries (ICs) in $t$ time

$\alpha=$ Intercept

$\beta_{1}$ dan $\beta_{2}=$ regression coefficient

$\mathrm{e}=$ error

Third, the hypotheses test. A hypothesis is a temporary answer to the formulation of research problems, where the formulation of research problems has been expressed in the form of questions (Sugiyono, 2015). Thus, the hypothesis can also be expressed as a theoretical answer to the formulation of a research problem, not yet an empirical answer. This test is used to test the effect of independent variables. Testing is done by using significance level $(\alpha=0,05)$ or $5 \%$ (Rahmawati \& Asyikin, 2016). The criteria for rejecting or accepting hypotheses, at the error rate used at $5 \%$ or 0.05 at the $95 \%$ significance level are:

a. If $t_{\text {count }}>t_{\text {table, }} \mathrm{H}_{0}$ is accepted and $\mathrm{H}_{a}$ is rejected. It means the coefficient of multiple correlations is significant.

b. If $t_{\text {count }}>$ table, $\mathrm{H}_{0} \mathrm{~s}$ rejected and $\mathrm{H}_{a}$ is accepted. It means the coefficient of multiple correlations is significant and shows there is a partial influence. 


\section{Results and Discussion}

A descriptive statistics analysis was conducted with the results presented in Table 2. Descriptive statistics are used to provide a description of the object under study through the sample data or population by not generalizing or making conclusions that apply to the public (Sugiyono, 2015: 61). The data are presented by using the tables and explained the value of maximum, minimum, median, mean and deviation standard.

Table 2 shows that the number of observations in this study was 115 data. The data in regards to return on equity indicate that the mean value of 13.3069 with standard deviation of 9.40348 . The minimum value of $0.14 \%$ was in the Bekasi Asri Pemula Tbk company [S] in 2016. Meanwhile, the maximum value of $52.43 \%$ was in the Modernland Realty Tbk. [S] company in 2013. Thus, return on equity data were pretty good. This was because the deviation of data was relatively small where the standard deviation value was less than the mean value.

Table 2 Results of descriptive statistics test

\begin{tabular}{lccc}
\hline & $\begin{array}{c}\text { Return on Equity } \\
(\mathrm{Y})\end{array}$ & $\begin{array}{c}\text { Audit Quality } \\
\left(\mathrm{X}_{1}\right)\end{array}$ & $\begin{array}{c}\text { Proportion of Independent } \\
\text { Board of Commissioners- } \\
\text { ICs }\left(\mathrm{X}_{2}\right)\end{array}$ \\
\hline Observation & 115 & 115 & 115 \\
Minimum & 0.14 & 2.00 & 0.20 \\
Maximum & 52.43 & 5.00 & 0.83 \\
Mean & 13.3069 & 3.9304 & 0.3964 \\
Std. Deviation & 9.40348 & 0.84523 & 0.11284 \\
\hline
\end{tabular}

Source: EViews output

The audit quality data show a mean value of 3.9304 and a standard deviation of 0.84523 . The minimum number was 2 at Megapolitan Development Tbk company. Whereas, the maximum was 5 where one of them is at Agung Podomoro Tbk company. Thus, the quality of audit data was quite good. This was because the deviation of data was relatively small where the standard deviation value was less than the mean value.

Dependent Variable: ROE

Table 3 The results of common effect model

Method: Panel Least Squares

Date: 03/02/18 Time: 13:27

Sample: 20122016

Periods included: 5

Cross-sections included: 23

Total panel (balanced) observations: 115

\begin{tabular}{|c|c|c|c|c|}
\hline Variable & Coefficient & Std. Error & $\mathrm{t}$-Statistic & Prob. \\
\hline C & 1.687207 & 0.772423 & 2.184304 & 0.0310 \\
\hline $\mathrm{AQ}$ & 0.000656 & 0.325751 & 0.002015 & 0.9984 \\
\hline ICs & -1.107766 & 0.843428 & -1.313409 & 0.1917 \\
\hline R-squared & 0.015479 & \multicolumn{2}{|c|}{ Mean dependent var } & 0.997054 \\
\hline Adjusted R-squared & -0.002102 & \multicolumn{2}{|c|}{ S.D. dependent var } & 0.739058 \\
\hline S.E. of regression & 0.739834 & \multicolumn{2}{|c|}{ Akaike info criterion } & 2.260960 \\
\hline Sum squared resid & 61.30377 & \multicolumn{2}{|c|}{ Schwarz criterion } & 2.332567 \\
\hline Log likelihood & -127.0052 & \multirow{2}{*}{\multicolumn{2}{|c|}{ Hannan-Quinn criter. }} & 2.290025 \\
\hline F-statistic & 0.880451 & & & 1.728276 \\
\hline Prob(F-statistic) & 0.417445 & \multicolumn{2}{|c|}{ Durbin-Watson stat } & \\
\hline
\end{tabular}

Source: EViews output 
The proportion of ICs show that the mean value of 0.9364 or $93.64 \%$ with the deviation 0.11284 or $11.28 \%$. The highest value of 0.83 or $83 \%$ was Lippo Karawaci Tbk. [S] in 2016. The lowest value of 0.20 or 20\% was in Gowa Makassar Tourism Development Tbk. [S] in 2012. Thus, the proportion of independent board data was categorized quite well since relatively small data deviations in which the standard deviation value was less than the mean.

The results of regression analysis are presented in Table 3. Table 3 shows r-square value of 0.015479 $(1.5 \%)$ indicated that the ability of panel value variables describing audit quality and the proportion of independent board of commissioners was $1.5 \%$ and $98.5 \%$ of them were explained by other variables not found in the model. The probability of t-statistic coefficient of the auditing quality and the proportion of independent board of commissioners was not significant because of the magnitude of the $5 \%$ alpha in which the probability of the t-statistic value of audit quality was 0.998 which is lower than significance level of 0.05 , and the probability of t-statistic proportion of independent board of commissioners was 0.192 which is lower than significance level of 0.05 .

Table 4 Results of fixed effect model

Dependent Variable: ROE

Method: Panel Least Squares

Date: 03/02/18 Time: 13:28

Sample: 20122016

Periods included: 5

Cross-sections included: 23

Total panel (balanced) observations: 115

\begin{tabular}{crrrr}
\hline \hline Variable & Coefficient & Std. Error & t-Statistic & Prob. \\
\hline \hline C & 1.450614 & 1.858031 & 0.780726 & 0.4370 \\
AQ & 1.039752 & 0.737041 & 1.410712 & 0.1618 \\
ICs & -4.009823 & 1.808207 & -2.217568 & 0.0291 \\
\hline \hline
\end{tabular}

Effects Specification

Cross-section fixed (dummy variables)

\begin{tabular}{lrll}
\hline \hline R-squared & 0.283827 & Mean dependent var & 0.997054 \\
Adjusted R-squared & 0.092848 & S.D. dependent var & 0.739058 \\
S.E. of regression & 0.703913 & Akaike info criterion & 2.325335 \\
Sum squared resid & 44.59436 & Schwarz criterion & 2.922059 \\
Log likelihood & -108.7068 & Hannan-Quinn criter. & 2.567542 \\
F-statistic & 1.486168 & Durbin-Watson stat & 2.210473 \\
Prob(F-statistic) & 0.093256 & & \\
\hline \hline
\end{tabular}

Source: EViews output

Table 4 reveals a r-square value of $0.283827(28 \%)$ indicated that the ability of panel value variables describing audit quality and the proportion of independent board was $28 \%$ and $72 \%$ was explained by other variables not found in the model. The probability of $t$-statistic coefficient of audit quality was not significant because it was bigger than the magnitude of the alpha $5 \%(0.16>0.05)$ while the coefficient of the probability of t-statistic proportion of independent board was significant because it was smaller than alpha $5 \%(0.03<0.05)$.

Table 5 below shows that the R-Square (R2) value of $0.018430(1.8 \%)$ indicated that the ability of panel value variables describing audit quality and the proportion of independent board of directors was $1.8 \%$ and $98.2 \%$ were explained by other variables not found in the model. The coefficient of audit quality and proportion of independent board of commissioners was insignificant because the t-statistics probability of both variables is bigger than alpha $5 \%(\mathrm{AQ}=0.822>0.05$ and $\mathrm{ICs}=0.143>0.05)$. 
Table 5 Results of random effect model

Dependent Variable: ROE

Method: Panel EGLS (Cross-section random effects)

Date: 03/02/18 Time: 13:28

Sample: 20122016

Periods included: 5

Cross-sections included: 23

Total panel (balanced) observations: 115

Swamy and Arora estimator of component variances

\begin{tabular}{|c|c|c|c|c|}
\hline Variable & Coefficient & Std. Error & t-Statistic & Prob. \\
\hline $\mathrm{C}$ & 1.676919 & 0.841097 & 1.993729 & 0.0486 \\
\hline AQ & 0.079610 & 0.352935 & 0.225565 & 0.8220 \\
\hline ICs & -1.340590 & 0.910554 & -1.472280 & 0.1437 \\
\hline \multicolumn{5}{|c|}{ Effects Specification } \\
\hline & & & S.D. & Rho \\
\hline Cross-section random & & & 0.196134 & 0.0720 \\
\hline Idiosyncratic random & & & 0.703913 & 0.9280 \\
\hline \multicolumn{5}{|c|}{ Weighted Statistics } \\
\hline R-squared & 0.018430 & \multirow{5}{*}{\multicolumn{2}{|c|}{$\begin{array}{l}\text { Mean dependent var } \\
\text { S.D. dependent var } \\
\text { Sum squared resid } \\
\text { Durbin-Watson stat }\end{array}$}} & 0.846243 \\
\hline Adjusted R-squared & 0.000902 & & & 0.715124 \\
\hline S.E. of regression & 0.714802 & & & 57.22546 \\
\hline F-statistic & 1.051456 & & & 1.819670 \\
\hline Prob(F-statistic) & 0.352852 & & & \\
\hline \multicolumn{5}{|c|}{ Unweighted Statistics } \\
\hline R-squared & 0.014441 & \multirow{2}{*}{\multicolumn{2}{|c|}{$\begin{array}{l}\text { Mean dependent var } \\
\text { Durbin-Watson stat }\end{array}$}} & 0.997054 \\
\hline Sum squared resid & 61.36841 & & & 1.721898 \\
\hline
\end{tabular}

Source: EViews output

The best model of three was fix effect test because it has the highest R-Square $\left(R^{2}\right)$ value. An analysis of linear regression of panel data in this study used fixed effect method. Fixed Effects model was considered as the most appropriate data panel analysis method to test panel data for this research. As shown in Table 8, the result of regression in fixed effect model showed that value of audit quality coefficient equal to 0.039752 with positive parameter $(+)$ and coefficient value of proportion of independent board of equal to -4.009823 with negative parameter (-) and r-square value equal to $0.283827(28 \%)$ indicated that audit quality and proportion of independent board of commissioners were able to show the financial performance of $28 \%$ and the remaining $72 \%$ were explained by other variables not counted in this model. The probability value of audit quality of 0.1618 had no significant effect because it has bigger value than the magnitude of alpha $5 \%(0.1618>0.05)$, and the probability value of independent board of commissioner equal to 0.0291 had the significant effect because it is smaller than alpha $5 \%(0.0291>0.05)$. 
Table 6 Results of fixed effect model

Dependent Variable: ROE

Method: Panel Least Squares

Date: 03/02/18 Time: 13:28

Sample: 20122016

Periods included: 5

Cross-sections included: 23

Total panel (balanced) observations: 115

\begin{tabular}{|c|c|c|c|c|}
\hline Variable & Coefficient & Std. Error & $\mathrm{t}$-Statistic & Prob. \\
\hline $\mathrm{C}$ & 1.450614 & 1.858031 & 0.780726 & 0.4370 \\
\hline AQ & 1.039752 & 0.737041 & 1.410712 & 0.1618 \\
\hline ICs & -4.009823 & 1.808207 & -2.217568 & 0.0291 \\
\hline \multicolumn{5}{|c|}{ Effects Specification } \\
\hline \multicolumn{5}{|c|}{ Cross-section fixed (dummy variables) } \\
\hline R-squared & 0.283827 & \multicolumn{2}{|c|}{ Mean dependent var } & 0.997054 \\
\hline Adjusted R-squared & 0.092848 & \multicolumn{2}{|c|}{ S.D. dependent var } & 0.739058 \\
\hline S.E. of regression & 0.703913 & \multicolumn{2}{|c|}{ Akaike info criterion } & 2.325335 \\
\hline Sum squared resid & 44.59436 & \multicolumn{2}{|c|}{ Schwarz criterion } & 2.922059 \\
\hline Log likelihood & -108.7068 & \multicolumn{2}{|c|}{ Hannan-Quinn criter. } & 2.567542 \\
\hline F-statistic & 1.486168 & \multicolumn{2}{|c|}{ Durbin-Watson stat } & 2.210473 \\
\hline Prob(F-statistic) & 0.093256 & & & \\
\hline
\end{tabular}

Source: EViews output

Further, this study conducted hypotheses test to see which independent variables have a partial influence on the dependent variable and simultaneously testing the hypothesis by looking at the value of tcount or the level of significance of each variable. In this test, the measuring instrument used was the value of tcount should be greater than table or the probability value of significance should be smaller than 0.05 .

The first hypothesis obtained tcount as $1.4107<$ ttable as 1.981 with probability value was $0.1618>$ alpha 0.05 . Consequently, $\mathrm{H}_{1}$ is not supported. The results of the first hypothesis testing show that audit quality variables did not affect the financial performance. It was reflected in the return on equity (ROE) having the probability value of 0.1618 which was bigger than 0.05 . It showed that audit quality had the positive and insignificant influence on financial performance. The positive direction indicated that there was a tendency that the higher the quality of auditing level, the higher the auditor's expertise (the specialization), the higher the integrity of the financial statements, and the better the financial statements.

Agency theory assumes that a man is always pursue his self-interest, so the presence of an independent third party as a mediator on the relationship between principal and agent is indispensable. In this case, it means an independent auditor. Investors will be more inclined to accounting data resulting from high audit quality (Hardiningsih, 2010). Auditors with multiple clients in the same industry will have a deeper understanding of the specific audit risks representing the industry but will require more skill development than the auditor in general. This additional expertise will result in a positive return in audit fees, so it is assumed that auditors with high concentrations in certain industries will provide a higher quality.

The results of this study are in accordance with the research conducted by Hardiningsih (2010) who studied about the influence of independence, corporate governance and quality audit on the integrity 
of financial statements of companies listed on the Indonesia Stock Exchange in 2005-2008. The results showed that audit quality did not affect the integrity of financial statements

Whereas, the second hypothesis obtained value $t$ as $-2.2176<$ table as 1.981 with probability was 0.0291 <alpha 0.05 . Therefore, $\mathrm{H}_{2}$ is supported. The results of the second hypothesis test show that the proportion of independent board of commissioners had a negative and significant effect on financial performance as reflected in Return on Equity (ROE). It can be seen from probability value of 0.0291 which is smaller than 0.05 . It can be revealed that there was the influence of the proportion of independent board of commissioners to financial performance as reflected in return on equity, but negative sign meant it would have an impact on financial performance.

The magnitude of the proportion of independent commissioners does not affect the performance of the company. The increase and decrease in company performance are more influenced by factors other than the proportion of independent commissioners (Susanti, 2011). Independent commissioners act as mediators in disputes between internal managers, and oversee management policies and advise management. Supervision by an independent board of commissioners can improve the performance of managers so the performance of the company will also increase (Widyati, 2013).

This research is in line with Kusdiyanto \& Kusumaningrum (2015) who studied the influence of good corporate governance and leverage on financial performance (study on manufacturing companies listed at BEI 2013-2014). The results showed that the proportion of independent commissioners had a significant negative effect on the financial performance of the company. Supported by Djazilah \& Kurnia (2016), the research was on the influence of GCG mechanism and CSR disclosure on financial performance on manufacturing companies listed on Indonesia Stock Exchange 2012-2014. The results showed that the proportion of independent board of commissioners had a significant influence on the performance reflected on the return on equity. Moreover, the research conducted by Dewi (2012), was also about the influence of corporate governance and leverage on financial performance in banking that listed in BEI. The results showed that the proportion of independent commissioners had a significant negative effect on the financial performance of the company.

\section{Conclusions}

This study aims to examine the effect of good corporate governance implementation that is the quality of auditor (AQ) to financial performance and proportion of independent board of commissioner (ICs) to company financial performance. This research uses the purposive sampling method that is sampling technique which refers to certain criteria. Based on predetermined criteria, 23 companies will be selected as research samples in 2012 until 2016. The method of analysis used is the quantitative method, with classical assumption test and panel data regression analysis. From the three tests obtained the best model is Fixed Effect Model (FEM).

The results of this study show some important results as follows. First, audit quality had the positive and insignificant effect on return on equity with significant value $0.1618>0.05$ and tcount was bigger than table, so $\mathrm{H}_{1}$ is supported. Second, the proportion of independent board of commissioners had a negative and significant effect on return on equity with probability value $0.0291<0.05$, and tcount was smaller than table, so $\mathrm{H}_{2}$ is supported.

\section{References}

Aziz, A., \& Hartono, U. (2017). Pengaruh good corporate governance, struktur modal, dan leverage terhadap kinerja keuangan perusahaan pada sektor pertambangan yang terdaftar di Bursa Efek Indonesia tahun 2011-2015. Jurnal Ilmu Manajemen, 5(3), 1-13.

Christiani, I., \& Nugrahanti, Y. W. (2014). Pengaruh kualitas audit terhadap manajemen laba. Jurnal Akuntansi dan Keuangan, 16(1), 52-62. Retrieved from https://doi.org/10.9744/jak.16.1.52-62

Dewi, A. S. (2012). Pengaruh corporate governance dan laverage terhadap kinerja keuangan pada perbankan yang terdaftar di BEI. Kajian Akuntansi dan Auditing, 7(1), 61-71.

Djazilah, R., \& Kurnia. (2016). Pengaruh mekanisme GCG dan pengungkapan CSR terhadap kinerja keuangan. Jurnal Ilmu dan Riset Akuntansi, 5(10), 1-19. 
Eva, E., \& Artinah, B. (2016). Pengaruh pelaksanaan good corporate governance, kepemilikan institutional dan laverage terhadap kinerja keuangan (Studi pada industri perbankan di Bursa Efek Indonesia). Manajemen dan Akuntansi, 17(April), 17-28.

Fahruri, A. (2017). Pengaruh corporate governance, loan to deposit ratio, nonperforming loan, inflasi dan kurs terhadap kinerja keuangan perusahaan perbankan yang terdaftar di Bursa Efek Indonesia pada tahun 2007-2010, XV(1), 63-70.

Hardiningsih, P. (2010). Pengaruh independensi, corporate governance, dan kualitas audit terhadap integritas laporan keuangan. Jurnal Kajian Akuntansi, 2(1), 61-76.

Hasanah, I., Susyanti, J., \& Wahono, B. (2017). Analisis kinerja keuangan perusahaan real estate dan property yang terdaftar di Bursa Efek Indonesia sebelum dan selama pemerintahan presiden Jokowi. Jurnal Warta Ekonomi, 7(17), 47-63.

Kusdiyanto, \& Kusmaningrum, D. D. (2015). Pengaruh good corporate governance dan laverage terhadap kinerja keuangan (Studi pada perusahaan manufaktur yang terdaftar di BEI 2013-2014). Jurnal Managemen dan Bisnis, 19(2), 161-167.

Perdana, H. D., Putra, R. P., \& Murni, S. (2016). Corporate governance dan kinerja keuangan perusahaan (studi pada perusahaan Indonesia di Indeks LQ45 tahun 2010-2014). Jurnal Akuntansi, $4(1), 1-10$.

Rahmawati, N., \& Asyikin, J. (2016). Pengaruh corporate governance perception index terhadap kinerja keuangan perusahaan yang terdaftar di Bursa Efek Indonesia periode 2009-2013. Jurnal Manajemen dan Akuntanti, 17(April), 53-66.

Setiawan, B. (2015). Pengaruh independensi, kualitas audit dan mekanisme corporate governance terhadap integritas laporan keuangan perusahaan manufaktur di Bursa Efek Indonesia tahun 2008-2012. Jom FEKON, 2(2), 1-15.

Sugiyono. (2015). Statistik Nonpaametris Untuk Penelitian. (B. R. Setiadi, Ed.). Yogyakarta: Penerbit Alfabeta Bandung.

Susanti, S. I. A. (2011). Pengaruh kualitas corporate governance, kualitas audit, dan earnings management terhadap kinerja perusahaan. Junal Ekonomi dan Bisnis, 5(2), 145-161.

Sutrisno. (2012). Manajemen Keuangan: Teori Konsep \& Aplikasi (1st ed.). Yogyakarta: Penerbit Ekonisia.

Widyati, M. F. (2013). Pengaruh dewan direksi, komisaris independen, komite audit, kepemilikan manajerial dan kepemilikan institutional terhadap kinerja keuangan. Jurnal Ilmu Manajemen, 1(1), 234-249.

Winarno, W. W. (2015). Analisis Ekonometrika dam Statistika dengan EViews. 4th ed. Yogyakarta: UPP STIM YKPN. 